Original article

Original articles

https://doi.org/10.17308/kcmf.2021.23/3303

\title{
Ozone detection by means of semiconductor gas sensors based on palladium (II) oxide
}

\author{
S. V. Ryabtsev ${ }^{1 \bowtie}$, D. A. A. Ghareeb ${ }^{1}$, A. A. Sinelnikov ${ }^{1}$, S. Yu. Turishchev ${ }^{1}$, L. A. Obvintseva ${ }^{2}$, \\ A. V. Shaposhnik ${ }^{3}$
}

\author{
${ }^{1}$ Voronezh State University, \\ 1 Universitetskaya pl., Voronezh 394018, Russian Federation \\ ${ }^{2}$ Russian State University named after A. N. Kosygin, \\ 1 Malaya Kaluzhskaya str., Moscow 119071, Russian Federation \\ ${ }^{3}$ Voronezh State Agricultural University, \\ 1 Michurina ul., Voronezh 394087, Russian Federation
}

\begin{abstract}
Thin film semiconductor sensors based on palladium oxide were produced to analyse the concentration of ozone in the air. The palladium oxide films were obtained by means of thermal oxidation of $\sim 20-30 \mathrm{~nm}$ metal in air at various temperatures. The oxide films were studied using electron microscopy and reflection high-energy electron diffraction. The optical, electrophysical, and gas sensitivity properties of the films were investigated. The study determined the optimal oxidation annealing temperature that ensures the uniform composition of the films and absence of electrical noise affecting the gas detection process. The article explains that electrical noise in ultrathin films is caused by their fragmentation during oxidation annealing. The study demonstrated the high sensitivity of the obtained films to oxide.
\end{abstract}

Keywords: Palladium oxide, Ultrathin films, Electron microscopy, Reflection high-energy electron diffraction, Phase composition, Electrical noise, Gas sensitivity properties, Ozone

Acknowledgements: the study was supported by the Russian Foundation for Basic Research (project No. 20-03-00901). TEM was conducted at the Centre for Collective Use of Scientific Equipment of Voronezh State University (http://ckp.vsu.ru.).

For citation: Ryabtsev S. V., Ghareeb D. A. A., Sinelnikov A. A., Turishchev S. Yu., Obvintseva L. A., Shaposhnik A. V. Ozone detection by means of semiconductor gas sensors based on palladium (II) oxide. Kondensirovannye sredy $i$ mezhfaznye granitsy = Condensed Matter and Interphases. 2021;23(1): 56-61. https://doi.org/10.17308/kcmf.2021.23/3303

Для цитирования: Рябцев С. В., Гхариб Д. А. А., Синельников А. А., Турищев С. Ю., Обвинцева Л. А., Шапошник А. В. Детектирование озона в воздухе полупроводниковыми газовыми сенсорами на основе оксида палладия (II). Конденсированные среды и межфазные границы. 2021;23(1): 56-61. https://doi.org/10.17308/kcmf.2021.23/3303

Stanislav V. Ryabtsev, e-mail: ryabtsev@phys.vsu.ru

(c) Ryabtsev S. V., Ghareeb D. A. A., Sinelnikov A. A., Turishchev S. Yu., Obvintseva L. A., Shaposhnik A. V., 2021 


\section{Introduction}

At the moment, ozone-based technologies are widely used for the disinfection of water in water supply lines, swimming pools, and indoor water parks, as well as for sewage water treatment, the bleaching of paper, etc. Ozone is obtained in large quantities by means of special on-site generators. However, ozone is very toxic. The maximum acceptable concentration (MAC) of ozone in the operational area is $0.1 \mathrm{mg} / \mathrm{m}^{3}$ or $\sim 50 \mathrm{ppb}$ (1ppb - $10^{-7}$ vol. \%). For comparison, the MACs of other toxic gases, including $\mathrm{Cl}_{2}$, $\mathrm{NO}_{2}$, and $\mathrm{CO}, \mathrm{NH}_{3}$ are within the range of 300$3 \cdot 10^{4} \mathrm{ppb}$. Therefore, in order to ensure safety at the ozone generation stations, it is necessary to organise continuous and multipoint monitoring of the concentration of ozone in the air. The existing monitoring devices are based on optical techniques for ozone detection and have a number of drawbacks: they are expensive, require a lot of energy, and are difficult to service. Moreover, they only analyse the ozone concentration at a single point, the place where the optical sensor is located. An alternative solution involves using semiconductor-based resistive sensors. Devices with such sensors have a number of advantages: they do not require consumables and allow multipoint continuous monitoring of the air in the operational area.

The production technology of the gas sensitive layer and the choice of the sensor material largely determine the sensitivity of the sensor. The solgel method is the most commonly used. It helps to obtain highly developed surfaces available for the adsorption of gases. The article describes a thinfilm technology involving the vacuum deposition of gas sensitive layers, because it combines well with established microelectronic technologies. The cost of gas analysers produced using this technology is significantly lower.

$\mathrm{In}_{2} \mathrm{O}_{3}, \mathrm{WO}_{3}, \mathrm{ZnO}$, and $\mathrm{SnO}_{2}$ oxides are most commonly used as sensor materials for ozone detection, either in pure forms or with additives. In our study, we used PdO, which was first suggested as a sensor material for ozone analysis in our previous articles [1-3].

The purpose of the study was to optimise the technology of the production of thin gas sensitive PdO films that ensure detection of ozone, when its concentration is below the MAC.

\section{Experimental}

Thin PdO films were obtained by thermal sputtering of metallic Pd on various substrates: glass substrates for the study of the optical properties, alumina ceramic $\left(\mathrm{Al}_{2} \mathrm{O}_{3}\right)$ substrates for the analysis of the electrophysical and sensitivity properties, $\mathrm{KCl}$ single crystal substrates with an amorphous carbon sublayer in the experiments conducted using transmission electron microscopy (TEM). Fixed sputtering parameters, including the speed of the deposition of the metal on the substrate $(\sim 1 \mathrm{~nm} / \mathrm{min})$, the pressure of the residual gases in the vacuum chamber $\left(\sim 10^{-6} \mathrm{Torr}\right)$, and the distance between the evaporator and the substrate, allowed us to obtain metallic Pd films with reproducible thickness. The thickness of the films was determined by studying the film edge on a single crystal carbon substrate using a scanning electron microscope. The thickness of the experimental samples was $\sim 20-30 \mathrm{~nm}$. These metal films were annealed in air at 240,400 , and $600{ }^{\circ} \mathrm{C}$ for one hour. The obtained films were then characterised.

Optical analysis was performed using an Ocean Optics fibre optic spectrometer in transmission mode.

The phase composition and the microstructure of the films were studied by means of reflection high-energy electron diffraction (RHEED) and transmission electron microscopy (Karl Zeiss Libra 120).

The electrophysical and gas sensitivity properties of the films were studied on special alumina ceramic test structures. An alumina ceramic substrate $(2-3 \mathrm{~mm})$ plated with $\mathrm{Pt}$ electrodes used for measuring the resistance of PdO films is presented in Fig.1.

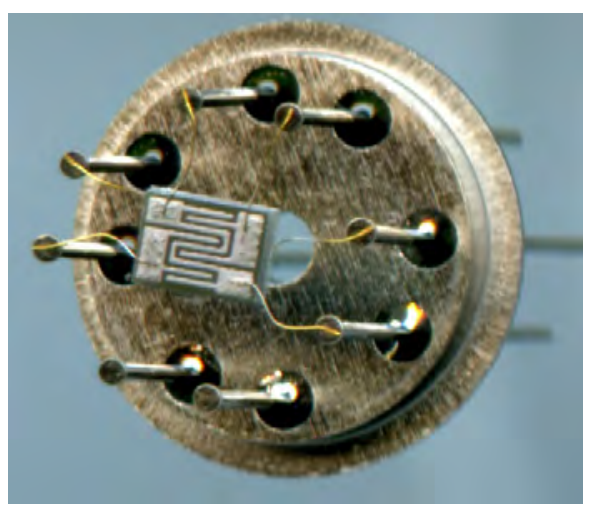

Fig. 1. The test structure used for the analysis of the electrophysical and gas sensitivity properties of the PdO films 
On the back side of the substrate a meander Pt heater was made. It served as a temperature sensor. The temperature of the sensors during the experiments was maintained with an accuracy of $1{ }^{\circ} \mathrm{C}$.

A GS-024-25 ozone generator (“OPTEC”) was used in the gas sensitivity experiments.

\section{Results and discussion}

$\mathrm{PdO}$ is a semiconductor oxide of the $p$-type with the bandgap of $2.2-2.7 \mathrm{eV}$ [4-6]. The semiconductor nature of the obtained films was proved by means of optical spectroscopy and electrophysical methods. The transmission spectra of PdO films are characteristic of semiconductor materials with transmission rapidly reducing next to the band-to-band electronic transition Ev-Ec (Fig. 2). A Tauc plot $E-(\alpha d h v)^{2}$ was applied to determine the bandgap of the semiconductor $E_{\mathrm{g}}$. Extrapolation of the straight line drawn to the linear region of the optical spectrum to the X-axis results in $E_{\mathrm{g}}=2.27 \mathrm{eV}$ (Fig. 2), which complies with the results of previous studies [4-6].

The p-type conductivity of PdO was determined earlier in the study of the Seebeck effect in thin films [3]. This is also proved by the

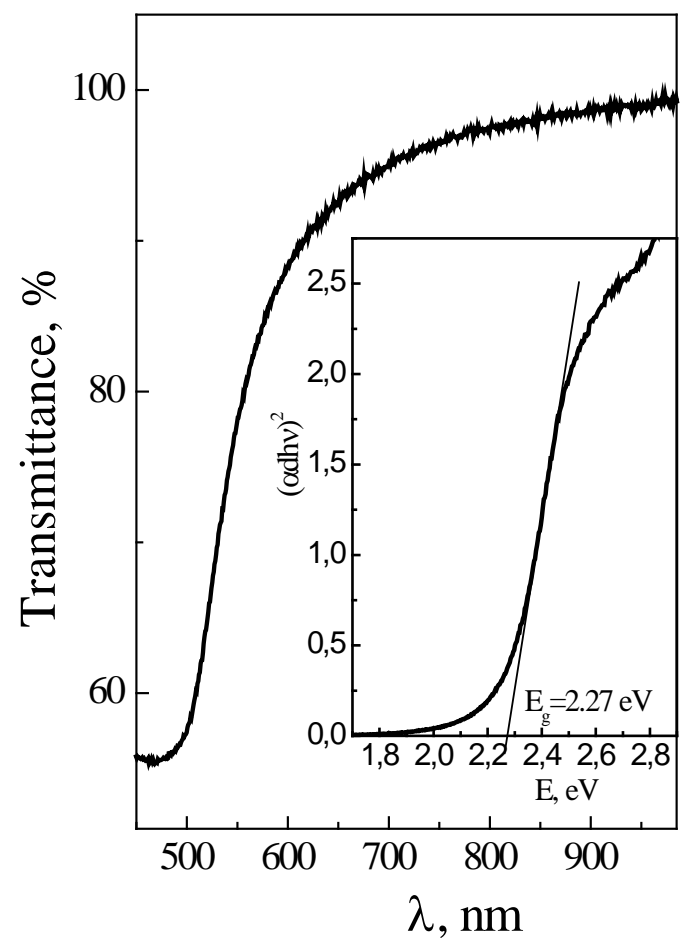

Fig. 2. Optical spectra of PdO nature of the resistance response of $\mathrm{PdO}$ films in the ozone - oxide gas environment (Fig. 4). The resistance of the PdO films, as expected from a $p$-type semiconductor, reduces in the oxidizing environment of ozone (Fig. 4) in full compliance with the known patterns of sensory response [7].

Fig. 3 presents X-ray diffraction patterns and TEM images of the Pd films in various stages of oxidation. The analysis of the X-ray diffraction patterns demonstrated that the initial films (Fig. 3a) are metallic palladium with no visible traces of oxide phases. Films annealed in air at $240{ }^{\circ} \mathrm{C}$ (PDF card 00-041-1043 [8]) have the same phase composition.

Increasing the temperature of annealing of $\mathrm{Pd}$ films in air up to 400 and $600{ }^{\circ} \mathrm{C}$ results in the formation of the tetragonal oxide phase of $\mathrm{PdO}$ with the following parameters of the crystal lattice: $a=0.3036 \mathrm{~nm}, c=0.5339 \mathrm{~nm}$ (PDF card 00-041-1107). In this case, RHEED does not show the metallic palladium phase in the films, which means that the oxidation of palladium is complete and the film now has a single phase - PdO.

One of the features of the oxidation annealing is the growth of crystallites both in the Pd film (Fig. 3b) and in the PdO films (Fig. 3c, d). In this case the films lose their initial uniform structure. The growth of crystallites and formation of gaps in the film proceeds in proportion to the growth of the annealing temperature. Such secondary recrystallization significantly affects the electrophysical properties of the films. During the oxidation annealing of the films applied to test structures (Fig. 1) we registered their current resistance, which monotonously grew with the growth of temperature. This was mainly accounted for by the oxidation of metallic palladium to the semiconductor oxide which has higher resistance.

It is noteworthy, that at annealing tempera tures of more than $550{ }^{\circ} \mathrm{C}$, electrical noise was observed which, according to the microscopic study (Fig. 3), was directly connected to the fragmentation of the thin films. We assume that the increasing fragmentation of the films results in worse contact between the crystallites, which causes the electrical noise. At a temperature of above $600{ }^{\circ} \mathrm{C}$, the noise level and the resistance grow dramatically. At a temperature of 650$700{ }^{\circ} \mathrm{C}$, the films fragmentation ends and as a 

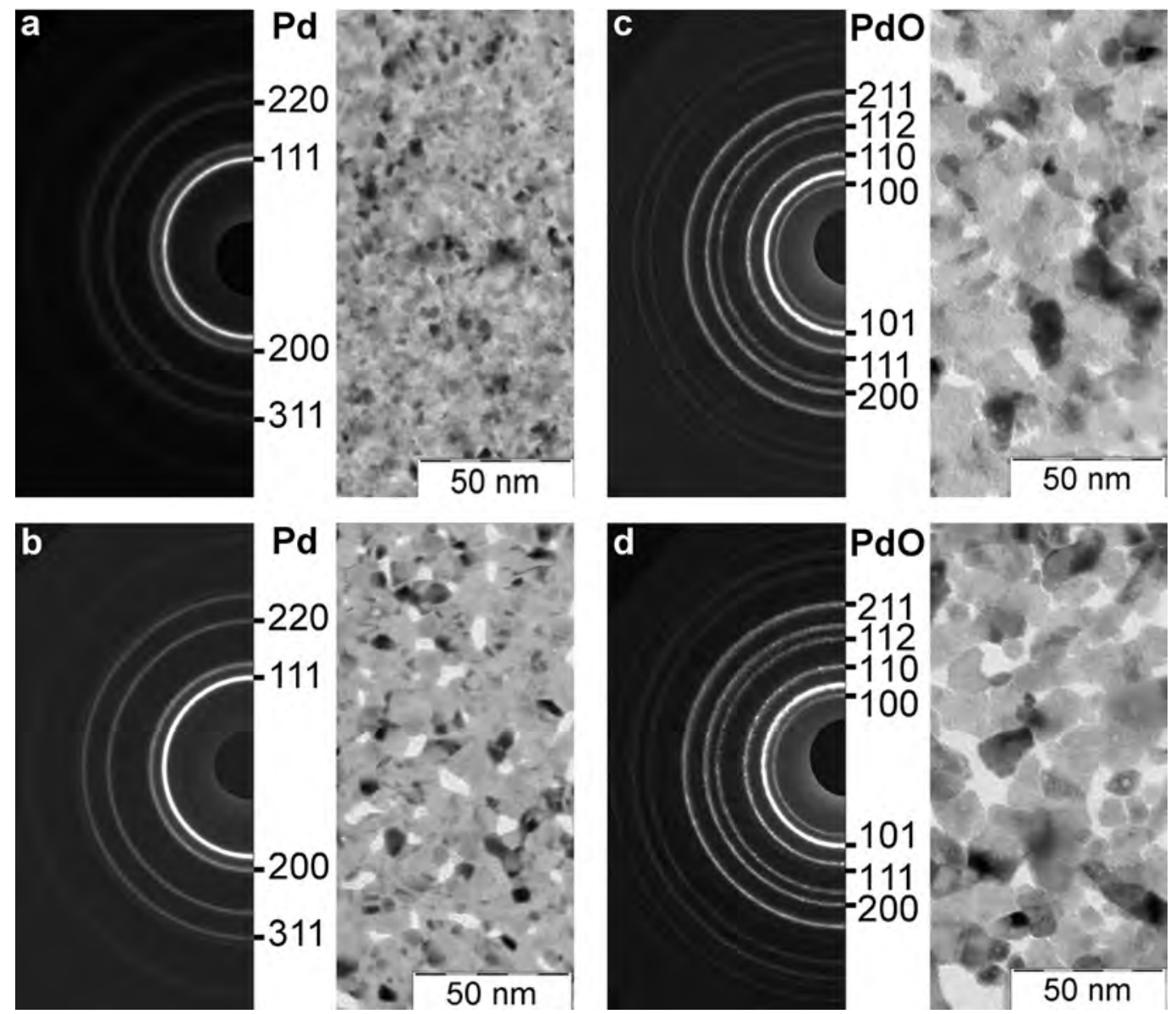

Fig. 3. X-ray diffraction patterns and TEM images of the initial Pd film (a) and the films annealed at 240 (b), 400 (c), and $600{ }^{\circ} \mathrm{C}(\mathrm{d})$

result the films lose their electrical conductivity.

The described patterns are characteristic for the thin films $(\sim 20-30 \mathrm{~nm})$ described in this article. The thickness of the films was chosen because of the ratio of the surface area to the volume, i.e. the sensory effect of the films depends on the gas chemisorption. The inner "exchange" layers of the films remain passive and shunt the changes in the electrical conductivity of the surface layers, thus reducing the sensory effect.

Therefore, the optimal annealing temperature for PdO thin films should not exceed $550^{\circ} \mathrm{C}$. This ensures the single-phase composition of the films and the absence of electrical noise that interferes with accurate resistance measurements.

The gas sensitive properties of $\mathrm{PdO}$ thin films were studied, when the concentrations of ozone in the air were $25,55,90$, and $250 \mathrm{ppb}$. The operating temperature of the $\mathrm{PdO}$ films during the ozone detection experiments was $150^{\circ} \mathrm{C}$. The resistance response of the PdO based thin

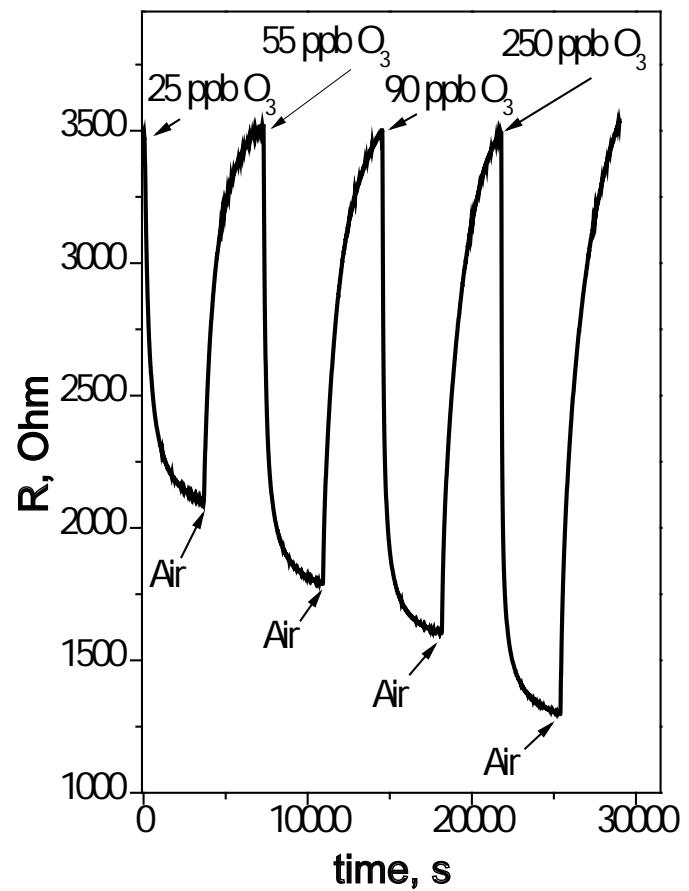

Fig. 4. The resistance response of the PdO films to various concentrations of ozone in the air 
film sensor obtained by means of the described technology is presented in Fig. 4.

The literature review demonstrated that the minimal concentrations of ozone registered by semiconductor sensors are from single digit to several tens of ppb [9-12]. Fig. 4 demonstrates that the elaborated technology for the production of ultrathin layers of PdO can detect significantly lower concentrations of ozone in the operation area.

\section{Conclusions}

In our research, we analysed PdO ultrathin films and their potential as sensor materials for the detection of ozone in the air. The films were obtained by means of thermal oxidation of the layers of metallic palladium. TEM registered the fragmentation of PdO films at higher annealing temperatures, which results in electrical noise occurring during resistance measurements. The optimal oxidation annealing temperature is $550{ }^{\circ} \mathrm{C}$. The sensory layers obtained using this technology can detect ozone at concentrations significantly lower than $25 \mathrm{ppb}$.

\section{Conflict of interests}

The authors declare that they have no known competing financial interests or personal relationships that could have influenced the work reported in this paper.

\section{References}

1. Ryabtsev S. V., Ievlev V. M., Samoylov A. M., Kuschev S. B., Soldatenko S. A. Microstructure and electrical properties of palladium oxide thin films for oxidizing gases detection. Thin Solid Films. 2017;636: 751-759. https://doi.org/10.1016/j.tsf.2017.04.009

2. Ryabtsev S. V., Shaposhnik A. V., Samoylov A. M., Sinelnikov A. A., Soldatenko S. A., Kuschev S. B., Ievlev V. M. Thin films of palladium oxide for gas sensors. Doklady Physical Chemistry. 2016;470(2): 158-161.https://doi.org/10.1134/S0012501616100055

3. Ievlev V. M., Ryabtsev S. V., Samoylov A. M., Shaposhnik A. V., Kuschev S. B., Sinelnikov A. A. Thin and ultrathin films of palladium oxide for oxidizing gases detection. Sensor and Actuators B. 2018;255(2): 1335-1342.https://doi.org/10.1016/j.snb.2017.08.121

4. Heras J. M., Estiu G., Viscido L. Annealing behaviour of clean and oxygen covered polycrystalline palladium films: a work function and electrical resistance study. Thin Solid Films. 1990;188(1): 165172. https://doi.org/10.1016/0040-6090(90)90202-O
5. Nilsson P. O., Shivaraman M. S. Optical properties of PdO in the range 0.5-5.4 eV. Journal of Physics C: Solid State Physics. 1979;12(7): 1423-1427. https://doi.org/10.1088/0022-3719/12/7/030

6. Sobolev V. Val., Mordas D. O., Sobolev V. V. Optical spectra of palladium oxide. Glass Physics and Chemistry. 2003;29(4): 360-363. https://doi. org/10.1023/a:1025116708801

7. Semiconductor sensors in physico-chemical studies. In: Handbook of sensors and actuators Vol. 4. Kupriyanov L. Yu. (ed.). Amsterdam-Lausanna-New York-Oxford-Shannon-Tokio: Elsevier; 1996. 412 p. ISBN 5-02-001542-3

8. Powder Diffraction File. Alphabetical Index. Inorganic Compounds. JCPDS.

9. Korotcenkov G., Brinzari V., Cho B. K. $\operatorname{In}_{2} \mathrm{O}_{3}$ - and $\mathrm{SnO}_{2}$-based ozone sensors: Design and characterization. Critical Reviews in Solid State and Materials Sciences 2017;43(2): 83-132. https://doi.org/10.1080/1040843 6.2017 .1287661

10. Takada T. Ozone detection by $\ln _{2} \mathrm{O}_{3}$ thin film gas sensor. In: Chemical Sensor Technology. V. 2. Seiyama T. (ed.). Tokyo: Koudansha, Amsterdam: Elsevier; 1989.59-70 p.https://doi.org/10.1016/b9780-444-98784-6.50009-x

11. Takada T., Tanjou H., Saito T., Harada K. Aqueous ozone detector using In2O3 thin-film semiconductor gas sensor. Sensors and Actuators $B$. 1995;25(1-3): 548-551.https://doi.org/10.1016/09254005(95) $85119-4$

12. Obvintseva L. A. Poluprovodnikovye metallooksidnye sensory dlya opredeleniya khimicheski aktivnykh gazovykh primesei v vozdushnoi srede [Semiconductor metal oxide sensors for the determination of chemically active gas impurities in air]. Rossiiskii khimicheskii zhurnal. 2008;52(2): 113121. Available at: https://www.elibrary.ru/item. asp?id=11629686 (In Russ.)

\section{Information about the authors}

Stanislav V. Ryabtsev, DSc in Physics and Mathematics, Senior Researcher, Department of Solid State Physics and Nanostructures, Voronezh State University, Voronezh, Russian Federation; e-mail: ryabtsev@phys.vsu.ru. ORCID iD: https://orcid. org/0000-0001-7635-8162.

Dina A. A. Ghareeb, postgraduate student, Department of Solid State Physics and Nanostructures, Voronezh State University; Voronezh, Russian Federation.

Alexander A. Sinelnikov, $\mathrm{PhD}$ in Physics and Mathematics, Head of the Department of Materials Science and Nanotechnology, Voronezh State University, Voronezh, Russian Federation; e-mail: rnileme@mail.ru. 
Sergey Yu. Turishchev, DSc in Physics and Mathematics, Associate Professor, Department of Solid State Physics and Nanostructures, Voronezh State University, Voronezh, Russian Federation; e-mail: tsu@phys.vsu.ru. ORCID iD: https://orcid.org/00000003-3320-1979.

Lyudmila A. Obvintseva, $\mathrm{PhD}$ in Physics and Mathematics, Russian State University named after A. N. Kosygin, Moscow, Russian Federation; e-mail: obvint@yandex.ru.
Aleksey V. Shaposhnik, DSc in Chemical Sciences, Professor, Head of the Department of Chemistry, Voronezh State Agrarian University named after Emperor Peter the Great, Voronezh, Russian Federation; e-mail: ash@agrochem.vsau.ru. ORCID iD: https:// orcid.org/0000-0002-1214-2730.

All authors have read and approved the final manuscript.

Received 25 December 2020; Approved after reviewing 15 January 2021; Accepted 15 March 2021; Published online 25 March 2021.

Translated by Yulia Dymant

Edited and proofread by Simon Cox 